\title{
A Comparative Study of Foreign Language Anxiety and Motivation of Academic- and Vocational-Track High School Students
}

\author{
Hui-ju Liu ${ }^{1} \&$ Chien-wei Chen ${ }^{2}$ \\ ${ }^{1}$ Department of English, Da-Yeh University, Taiwan \\ ${ }^{2}$ National Yuanlin Chung-Shih Industrial Vocational High School, Taiwan \\ Correspondence: Hui-ju Liu, Department of English, Da-Yeh University, Taiwan. E-mail: \\ carlota@mail.dyu.edu.tw
}

\author{
Received: December 5, 2014 Accepted: January 7, 2015 Online Published: February 13, 2015 \\ doi:10.5539/elt.v8n3p193 URL: http://dx.doi.org/10.5539/elt.v8n3p193
}

\begin{abstract}
This study aimed to investigate EFL learner language anxiety and learning motivation of high school students. Subjects included 155 students from the same private senior high school in central Taiwan, 60 in academic track and 95 in vocational track. The majority of the participants started taking English lessons either before entering elementary school or during the first two years in elementary school. Statistical methods were conducted to investigate 1) whether learner motivation and language anxiety significantly vary between academic- and vocation-track high school students, 2) whether both academic- and vocational-track high school students feel an above-average level of language anxiety, and 3) whether there is a significant relationship between language anxiety and motivation among the EFL high school students. The findings of the study revealed that first, both groups of students felt moderate levels of language anxiety; there were no significant differences in anxiety level between the two groups of students. Second, students in the academic-track were also found to have higher extrinsic motivation and overall learning motivation than their vocational-track counterparts. Furthermore, a significant negative relationship was identified between the two important affective variables, motivation and anxiety. Important pedagogical implications for English teachers were discussed in the study.
\end{abstract}

Keywords: foreign language anxiety, learning motivation, foreign language learning

\section{Introduction}

To obtain a better command of English in an EFL context has inevitably become a great challenge for most students in Taiwan. A variety of factors may affect student language learning performance, e.g., the learning environment, learning methods, self-confidence, and family background. Gardner (1985) pointed out that motivation is a core element along with language aptitude in determining the success of learning another language in the classroom setting. A positive and strong learning motivation on the part of students is essential for achieving language learning. In contrast, if they lack motivation, they may have low interest in English and their examination scores may suffer, so they would encounter disappointment and setback while learning English. Language anxiety is another important variable that may affect learners' language achievement. In general, everyone experiences some level of anxiety when they feel stressful or nervous about a certain situation. According to E. Horwitz, M. Horwitz, and Cope (1986), foreign language anxiety is situation-specific; students may suffer from strained feelings when they learn English as a second or foreign language.

In Taiwan, when students graduate from junior high schools, they basically have two choices for further education at this level. They can choose to enter a regular senior high school system or a vocational high school system. No matter what system they choose, they have to learn English in school. Whether they are in the academic or vocational track, if they want to enter a desirable university, they must take an entrance examination to achieve their goal. Since English is one of the major obligatory subjects, they need to get high scores on English so that they may enter their ideal university.

According to Chang (2006), most students choosing to enter the vocational high school system tended not to have very good English proficiency in junior high school; many students grew up in families of low socioeconomic status and lacked opportunities to practice English after school. Chen (2008) also indicated that "vocational high school students seldom achieved academic excellence when they were in the middle school" (p. 
13). This study, therefore, hopes to find out whether there are discrepancies between learning motivation and anxiety of the two groups of students. The research also attempts to help in obtaining more insight into the two important affective variables: motivation and anxiety, in the EFL context. Finally, it is expected that the findings can contribute to research in this dimension by providing teachers with some pedagogical information to enlighten learner motivation and deal with anxiety among different groups of students.

\subsection{Motivation in Language Learning}

As mentioned previously, motivation has been considered to be one of the most important factors of successful second and foreign language acquisition (Dörnyei , 1994; Ho, 1998; Noels, Clément, \& Pelletier, 1999; Noels, Pelletier, \& Vallerand, 2000; Oxford \& Shearin, 1994). Students who do not have sufficient motivation may not be able to persevere in accomplishing their goals during the long and oftentimes difficult language learning process. Although the term "motivation" is commonly understood as the driving force that keeps people moving to do something, definitions of motivation are numerous and varied, and there is much disagreement over the precise nature of motivation (Pintrich \& Schunk, 1996, p. 4). Over the last four decades, much research has been interested in providing more insights into the nature of motivation and its role in classroom learning and performance.

Gardner (1985), one of the pioneers who proposed motivation theory, defined motivation as "the combination of effort plus desire to achieve the goal of learning the language plus favorable attitudes toward learning the language" (p. 10). He and his colleagues conducted a great deal of research on language learning motivation within a framework of a socio-educational model (Gardner \& Lambert, 1959; Gardner, 1985, 1988; Gardner \& MacIntyre, 1991, 1993; Masgoret \& Gardner, 2003). In this model, there are two major motivation orientations for language learning: integrative and instrumental. Integrative orientation is related to positive attitudes toward the target language group, and perhaps desire to identify with members from that group. Instrumental orientation emphasizes the desire to achieve some practical goal, such as to enter a graduate school or to get job promotion. The integrative/instrumental distinction has inspired a considerable amount of research on language learning motivation. However, a number of criticisms began to surface by the 1990s (Au, 1988; Crookes \& Schmidt, 1991; Dörnyei , 1990; Oxford \& Shearin, 1994). One reason for the disparagement was that there were conflicting results about the relationship between integrative motive and language proficiency. Also, some researchers noticed that the orientations for learning a language in the second language learning context could be different from those in the foreign language learning context (Dörnyei , 1990; Noels, Pelletier, Clément, \& Vallerand, 2000; Schmidt, Boraie, \& Kassabgy, 1996).

Alternative theoretical approaches, including the self-determination theory, the attribution theory, and goal theories, have been put forward for a better understanding of language learning motivation (Dörnyei , 2003). Oxford and Shearin (1994) grouped motivation theories into four broad classes: need theories, instrumentality theories, equity theories, and reinforcement theories.

Deci and Ryan's (1985) self-determination theory has been one of the most influential ones in motivation research. They broadly divided orientations into three categories: intrinsic orientation, extrinsic orientation, and motivation (Ryan \& Deci, 2000a, 2000b). The orientations all lie on a continuum of self-determination, with intrinsic orientation lying on one end and motivation lying on the other. Intrinsic motivation refers to doing an activity for the inherent pleasure and interest derived from participation. Extrinsic motivation, on the other hand, refers to doing an activity for instrumental reasons, and it can be further classified into four different types of orientations based on how learners vary in the extent to which their self-regulation is autonomous. From the lowest to the highest levels of self-determination, they are: external regulation, introjected regulation, identified regulation, and integrated regulation (Noels, 2001b; Noels, Clément, \& Pelletier, 1999; Otis, Grouzet, \& Pelletier, 2005; Ryan \& Deci, 2000a). Learners who are neither extrinsically nor intrinsically motivated are amotivated and may experience feelings of incompetence to do something or helplessness regarding an outcome. Motivation is similar to the concept of "learned helplessness" (Noels, 2001a, p. 111).

While some of the research on language learning has linked motivational orientations to the self-determination theory (Jones, Llacer-Arrastia, \& Newbill, 2009; Noels, Pelletier, \& Vallerand, 2000), some has incorporated expectancy-value theories to examine language learners' motivation (Schmidt, Boraie, \& Kassabgy, 1996; Wen, 1997). Much research has also been undertaken to investigate the relationship between motivation and other language learning variables, e.g., anxiety and language achievement (Brown, Robson, \& Rosenkjar, 2001; Masgoret, Bernaus, \& Gardner, 2001) and strategy use (MacIntyre \& Noels, 1996; Okada, Oxford, \& Abo, 1996; Oxford \& Nyikos, 1989; Schmidt \& Watanabe, 2001). However, compared with the abundant research focusing on explaining and expanding the conceptual model of motivation, there are relatively fewer empirical studies on 
this important affective variable itself.

\subsection{Foreign Language Anxiety}

Language anxiety is often negatively associated with language performance (Aida, 1994; Awan, Azher, Anwar, \& Naz, 2010, Gardner, Tremblay, \& Masgoret, 1997; Horwitz, 1986; Marcos-Llinás \& Garau, 2009; Saito, Horwitz, \& Garza, 1999; Woodrow, 2006), and it is meaningful for many scholars to explore the potential sources in this dimension so that different language anxiety circumstances can be presented and understood. Young (1991) identified language anxiety sources and categorized them into six items: 1) personal and interpersonal anxiety, 2) language learners' beliefs about learning, 3) language instructors' beliefs about teaching, 4) instructor-learner interactive anxiety, 5) classroom procedures, and 6) language testing anxiety. Taking personal and interpersonal anxiety as one example, this type of anxiety may derive from problems, such as low self-esteem, competitiveness, communication apprehension, social anxiety, lack of group membership, and fear of losing one's self-identity or self-image (E. Horwitz, M. Horwitz, \& Cope, 1986; Young, 1990, 1991). Self-esteem can be associated with speaking anxiety. Individuals with low self-esteem tend to have fear of speaking in front of classmates. Young (1991) also pointed out that those students with self-perceived low ability level are very likely to experience language anxiety.

Onwuegbuzie, Bailey, and Daley (1997) investigated factors related to foreign language anxiety among 210 university students who were enrolled in French, Spanish, German or Japanese language courses. The analysis revealed fourteen variables which contributed significantly to the foreign language anxiety: "gender, age, academic achievement, semester course load, prior history of visiting foreign countries, prior high school experience with foreign languages, expected overall average for current language course, perceived intellectual ability, perceived scholastic competence, perceived appearance, perceived self-worth, cooperativeness, value placed on competitive learning, and academic locus of control" (Onwuegbuzie, Bailey, \& Daley, 1997, p. 6).

Researchers in Taiwan such as Hsu (2009) also analyzed language anxiety among 82 EFL technical college students. The results showed that males had higher test anxiety and fear of negative evaluation than female students did, whereas female students had higher communication apprehension anxiety. A significant negative correlation was identified between language anxiety and English proficiency. Students' language anxiety was negatively correlated with their study time after class. Further, the participants were found to feel most anxious about communicating with native speakers. The researcher suggested that teachers could design less stressful activities for courses to help students overcome foreign language anxiety and enhance student English learning performance.

Exploring the association between language anxiety and motivation among Taiwan junior high school students, Liu (2011) concluded that students with more English learning experience were less likely to feel anxious when learning the target language. Although these students tended to be subject to apprehension over negative evaluation from their peers and to have low confidence in their own ability, learner anxiety did not seem to influence the learning motivation and language performance of these young learners yet. A longitudinal study on foreign language anxiety among the EFL students was suggested for further research. In an earlier study, Liu (2010) found that motivation and anxiety were moderately correlated; motivation can serve as a significant predictor of language anxiety. Two motivation components, the desire to learn a language and motivational intensity, contributed to the prediction of language anxiety. She also pointed out that anxious learners tended to be "more susceptible to lower motivation, which can relate to lower proficiency" (p. 120).

\subsection{Research Questions}

The primary research questions of the current study are as follows:

1) Do learning motivation and language anxiety vary significantly between academic- and vocational-track high school students?

2) Do both academic- and vocational-track high school students experience an above-average level of language anxiety?

3) Is there a significant relationship between motivation and anxiety?

\section{Method}

\subsection{Participants}

There were the same numbers of male and female regular high school students in the study, whereas in the vocational track, there were obviously more females $(71.6 \%)$ than male $(28.4 \%)$ students (see Table 1 ). For regular high school students, the majority of them (63.3\%) started learning English in kindergarten. The others 
started learning a foreign language after they entered elementary school. Compared with the group of students in the regular track, a lower percentage of students in the vocational track (43.2\%) started learning English before entering the elementary school. More than half of them started learning English after they were elementary school students.

Table 1. Demographic information of the academic- and vocational-track high school students

\begin{tabular}{lll}
\hline & Academic & Vocational \\
\hline Gender & & \\
\hline Male & $30(50 \%)$ & $27(28.4 \%)$ \\
Female & $30(50 \%)$ & $68(71.6 \%)$ \\
\hline Time Starting Learning English & & \\
\hline Kindergarten & $38(63.3 \%)$ & $41(43.2 \%)$ \\
First or Second Grade & $14(23.3 \%)$ & $23(24.2 \%)$ \\
Third or Fourth Grade & $8(13.3 \%)$ & $20(21.1 \%)$ \\
Fifth or Sixth Grade & 0 & $8(8.4 \%)$ \\
Seventh Grade & 0 & $3(3.2 \%)$ \\
\hline
\end{tabular}

\subsection{Instruments}

The first instrument employed in the study to measure students' motivation was adapted from Pintrich, Smith, Garcia and McKeachie's (1991) Motivated Strategies for Learning Questionnaire (MSLQ). The MSLQ was originally designed to assess motivational orientations and strategy use of college students. It comprises two main sections: motivation and learning strategies. For the specific purpose of this study, only items in the motivation section were selected to be used in this study. They were 26 items developed to assess students' intrinsic goal orientation (items 1-4), extrinsic goal orientation (items 5-8), task value (items 9-14), control of learning beliefs (items 15-18), and self-efficacy for learning and performance (items 19-26).

Items in the dimension of intrinsic goal orientation assess the degree to which students perceive their engagement in a learning task for reasons such as "challenge, curiosity, and mastery" (Pintrich et al., 1991, p. 9). Items in the dimension of extrinsic goal orientation measure the degree to which students perceive their engagement in a task for reasons such as "grades, rewards, performance, evaluation by others, and competition" (ibid., p. 10). The task value subscale intends to measure how students perceive a task in terms of its importance and utility, as well as their interest in the task. The control of learning beliefs subscale assesses the degree to which students believe that their performance has a stronger association with their efforts rather than other factors, such as their teachers. Items in the self-efficacy subscale measures student confidence in their own ability and skills to complete a task. The researchers modified and translated the instrument into a Chinese version of 26 items. A six-point Likert scale $(1=$ strongly disagree; $2=$ disagree, $3=$ slightly disagree; $4=$ slightly agree; 5 =agree; $6=$ strongly agree) was employed for all items of the scale in this study. The reliability for the complete scale was .94 .

The well-acknowledged questionnaire, Foreign Language Classroom Anxiety Scale (FLCAS), was used in the study to measure learner anxiety in learning a foreign language. It was developed by Horwitz, Horwitz, and Cope (1986) and translated into a Chinese version by Liu (2010). The scale has 33 Likert-type items and is composed of three components: communication apprehension, test anxiety, and fear of negative evaluation in the EFL classroom. To avoid too many moderate responses from the participants, the Chinese five-point scale was changed into a six-point scale, ranging from 1 (strongly disagree) to 6 (strongly agree). The instrument used in a Taiwanese setting is quite reliable, yielding an alpha coefficient of .92.

\subsection{Data Analysis}

Before any statistical tests were conducted, all negative statements of anxiety items were reversely coded. To investigate the first research question concerning the significance of differences in language learning motivation and anxiety between regular and vocational high school students, multivariate analysis of variance (MANOVA) was performed. To ascertain whether the EFL high school students felt an above-average level of anxiety, the means and percentages of student responses to all 33 FLCAS item scores were examined. Finally, to determine whether learning motivation and anxiety are significantly related to learner anxiety, a Pearson product-moment correlation matrix for all the related variables was obtained and examined. 


\section{Results and Discussion}

\subsection{Differences in Motivation and Language Anxiety}

The means and standard deviations of scores on motivation and anxiety of both academic- and vocational-track high school students are presented in Table 1. To address the first research question concerning whether there are significant differences in the above-mentioned variables between the two groups of participants, MANOVA was performed on all of the scale and subscale scores. With regard to learner motivation, students in the vocational track had lower scores than their counterparts on all five motivation subscales; nonetheless, the only significant difference was found in extrinsic motivation $(F=5.16, p=.025)$. Also, it is noteworthy that in terms of overall motivation scores, regular high school students' motivation to learn English was significantly higher than their counterparts $(F=5.19, p=.024)$. The higher extrinsic motivation of regular high school students compared to those in the vocational track might be due to the greater demand for their performance from their school or due to their desire to get better grades to fulfill their own or parental expectations to enter an ideal university. The results were consistent with Chang's (2006) findings that most Taiwan regular high school students have higher learning motivation than vocational high school students. Some previous studies also indicated that students in the vocational track have lower motivation than those in regular high school (Chen, 2007; Han, 2009; Tsao, 2012). The current finding revealed that more attention is still needed to cultivate and increase vocational high school students' motivation. Also, teachers need to expend more efforts to improve the intrinsic motivation and self-efficacy of students in either group.

Table 2. Means and standard deviations of scores of motivation and anxiety

\begin{tabular}{lllll}
\hline \multirow{2}{*}{ Variable } & \multicolumn{2}{c}{ Regular } & \multicolumn{3}{c}{ Vocational } \\
\cline { 2 - 5 } & Mean & SD & Mean & SD \\
\hline Motivation & & & & \\
\hline Intrinsic & 17.08 & 3.08 & 16.43 & 2.75 \\
Extrinsic & 17.95 & 2.94 & 16.80 & 3.15 \\
Task & 27.35 & 3.59 & 26.04 & 4.47 \\
Belief & 18.30 & 3.49 & 17.78 & 3.20 \\
Efficacy & 30.35 & 8.07 & 28.35 & 7.56 \\
Overall & 111.03 & 15.50 & 105.40 & 14.68 \\
Anxiety & 121.20 & 24.60 & 116.22 & 24.58 \\
\hline
\end{tabular}

Note. Intrinsic $=$ Intrinsic Goal Orientation; Extrinsic $=$ Extrinsic Goal Orientation; Task $=$ Task Value; Beliefs $=$ Control of Learning Beliefs; Efficacy = Self-Efficacy.

Despite the fact that high school students in the vocational track tended to have lower anxiety scores than their counterparts in the regular track, the differences in this affect variable were not significant (see Table 3). The results suggested that although these students were in different tracks, they had similar levels of anxiety in the English classroom.

Table 3. MANOVA test results of differences in motivation and anxiety between students in the academic track and those in the vocational track

\begin{tabular}{llllll}
\hline Dependent variable & SS & df & MS & F & Sig. \\
\hline Motivation & & & & & \\
\hline Intrinsic & 15.62 & 1 & 15.62 & 1.89 & .172 \\
Extrinsic & 48.63 & 1 & 48.63 & 5.16 & $.025^{*}$ \\
Task & 62.91 & 1 & 62.91 & 3.65 & .058 \\
Belief & 9.98 & 1 & 9.98 & .911 & .341 \\
Efficacy & 147.48 & 1 & 147.48 & 2.45 & .120 \\
Overall & 1167.01 & 1 & 1167.01 & 5.19 & $.024^{*}$ \\
Anxiety & 911.63 & 1 & 911.63 & 1.51 & .221 \\
\hline
\end{tabular}

$* p<.05$. 


\subsection{Prevalence of Language Learning Anxiety}

To ascertain the levels of foreign language anxiety of both regular and vocational high school students, the percentages of students' responses to each answer choice of all 33 FLCAS items were examined. The mean and standard deviation of each anxiety item was also computed; the results are presented in Table 3. According to Liu (2011), an average item score of 3 or above indicated certain level of anxiety among the EFL students because the mean for each item can range from 0 to 6 on the Likert scale, and a higher value signifies a higher degree of anxiety. The results of the study showed that the means of the 33 anxiety items ranged from 2.97 to 4.33 for students in the academic track and 2.91 to 4.4 for those vocational-track students. Moreover, for the regular high school students, 32 out of 33 items had means above 3.0, and 22 item means were between 3.50 and 4.33. For vocational high school students, 30 items had means above 3.0, and 16 of the total 33 items had means between 3.50 and 4.40 . While students in the academic group had an average anxiety score of 3.67 on the anxiety scale, their counterparts had a slightly lower average score of 3.52 .

In sum, a moderate level of anxiety indeed existed among the participants when learning English in the EFL context. Vocational high school student may feel relaxed in English classes since they did not suffer as much stress from college entrance exam as their counterparts. However, the findings still suggest that teachers need to help both groups of students build more self-confidence and assist them to feel more motivated while learning English in the classroom.

Table 4. Percentages and means of anxiety item scores of regular and vocational high school students

\begin{tabular}{|c|c|c|c|c|c|c|c|c|}
\hline Item No. & 1 & 2 & 3 & 4 & 5 & 6 & Mean & SD \\
\hline \multicolumn{9}{|c|}{ 1. Never feel confident when speaking English in class } \\
\hline Regular & 3.3 & 11.7 & 10.0 & 45.0 & 18.3 & 11.7 & 3.98 & 1.24 \\
\hline Vocational & 7.4 & 13.7 & 16.8 & 41.1 & 15.8 & 5.3 & 3.60 & 1.27 \\
\hline \multicolumn{9}{|c|}{ 2.* Don’t worry about making mistakes } \\
\hline Regular & 3.3 & 13.3 & 33.3 & 31.7 & 11.7 & 6.7 & 3.55 & 1.17 \\
\hline Vocational & 3.2 & 13.7 & 22.1 & 26.3 & 25.3 & 9.5 & 3.85 & 1.30 \\
\hline \multicolumn{9}{|c|}{ 3. Feel uneasy about being called on in English class } \\
\hline Regular & 5.0 & 15.0 & 20.0 & 28.3 & 23.3 & 8.3 & 3.75 & 1.34 \\
\hline Vocational & 7.4 & 15.8 & 20.0 & 30.5 & 20.0 & 6.3 & 3.59 & 1.34 \\
\hline \multicolumn{9}{|c|}{ 4. Feel frightened not understanding what the teacher is saying } \\
\hline Regular & 0 & 16.7 & 21.7 & 31.7 & 23.3 & 6.7 & 3.82 & 1.17 \\
\hline Vocational & 9.5 & 10.5 & 25.3 & 37.9 & 11.6 & 5.3 & 3.47 & 1.26 \\
\hline \multicolumn{9}{|c|}{ 5.* Wouldn't feel bothered to take more English classes } \\
\hline Regular & 6.7 & 21.7 & 30.0 & 21.7 & 11.7 & 8.3 & 3.35 & 1.35 \\
\hline Vocational & 4.2 & 15.8 & 26.3 & 35.8 & 9.5 & 8.4 & 3.56 & 1.24 \\
\hline \multicolumn{9}{|c|}{ 6. Think about things having nothing to do with the course in English class } \\
\hline Regular & 1.7 & 16.7 & 10.0 & 55.0 & 11.7 & 5.0 & 3.73 & 1.09 \\
\hline Vocational & 10.5 & 9.5 & 27.4 & 31.6 & 12.6 & 8.4 & 3.52 & 1.36 \\
\hline \multicolumn{9}{|c|}{ 7. Always think that classmates are better at English } \\
\hline Regular & 1.7 & 10.0 & 11.7 & 31.7 & 25.0 & 20.0 & 4.28 & 1.29 \\
\hline Vocational & 3.2 & 5.3 & 13.7 & 31.6 & 22.1 & 24.2 & 4.37 & 1.31 \\
\hline \multicolumn{9}{|c|}{ 8.* Usually feel at ease during tests } \\
\hline Regular & 6.7 & 26.7 & 36.7 & 25.0 & 3.3 & 1.7 & 2.97 & 1.04 \\
\hline Vocational & 4.2 & 18.9 & 33.7 & 22.1 & 15.8 & 5.3 & 3.42 & 1.23 \\
\hline \multicolumn{9}{|c|}{ 9. Feel panicked when having to speak without preparation in English class } \\
\hline Regular & 0 & 15.0 & 16.7 & 33.3 & 23.3 & 11.7 & 4.00 & 1.22 \\
\hline Vocational & 9.5 & 10.5 & 18.9 & 35.8 & 15.8 & 9.5 & 3.66 & 1.38 \\
\hline \multicolumn{9}{|c|}{ 10. Worry about failing an English exam } \\
\hline Regular & 5.0 & 8.3 & 13.3 & 26.7 & 18.3 & 28.3 & 4.30 & 1.48 \\
\hline Vocational & 6.3 & 5.3 & 12.6 & 20.0 & 27.4 & 28.4 & 4.42 & 1.47 \\
\hline \multicolumn{9}{|c|}{ 11.* Understand why some people get so upset over English class } \\
\hline Regular & 0 & 1.7 & 11.7 & 50.0 & 25.0 & 11.7 & 4.33 & .90 \\
\hline
\end{tabular}




\begin{tabular}{|c|c|c|c|c|c|c|c|c|}
\hline Vocational & 3.2 & 3.2 & 14.7 & 43.2 & 26.3 & 9.5 & 4.15 & 1.09 \\
\hline \multicolumn{9}{|c|}{ 12. Forget things when getting nervous in English class } \\
\hline Regular & 3.3 & 25.0 & 20.0 & 26.7 & 18.3 & 6.7 & 3.52 & 1.32 \\
\hline Vocational & 8.4 & 23.2 & 27.4 & 26.3 & 10.5 & 4.2 & 3.20 & 1.27 \\
\hline \multicolumn{9}{|c|}{ 13. Feel embarrassed about volunteering to answer questions } \\
\hline Regular & 3.3 & 6.7 & 16.7 & 40.0 & 21.7 & 11.7 & 4.05 & 1.20 \\
\hline Vocational & 5.3 & 12.6 & 24.2 & 28.4 & 23.2 & 6.3 & 3.71 & 1.28 \\
\hline \multicolumn{9}{|c|}{ 14.* Would not be nervous speaking English with native English speakers } \\
\hline Regular & 5.0 & 15.0 & 30.0 & 38.3 & 11.7 & 0 & 3.37 & 1.04 \\
\hline Vocational & 3.2 & 11.6 & 22.1 & 38.9 & 12.6 & 11.6 & 3.81 & 1.24 \\
\hline \multicolumn{9}{|c|}{ 15. Get upset when not understanding the teacher's corrections } \\
\hline Regular & 3.3 & 16.7 & 26.7 & 33.3 & 15.0 & 5.0 & 3.55 & 1.19 \\
\hline Vocational & 8.4 & 15.8 & 34.7 & 27.4 & 9.5 & 4.2 & 3.26 & 1.21 \\
\hline \multicolumn{9}{|c|}{ 16. Fel uneasy even if well prepared for class } \\
\hline Regular & 3.3 & 25.0 & 28.3 & 28.3 & 10.0 & 5.0 & 3.32 & 1.20 \\
\hline Vocational & 9.5 & 22.1 & 38.9 & 21.1 & 5.3 & 3.2 & 3.00 & 1.15 \\
\hline \multicolumn{9}{|c|}{ 17. Often feel like not going to English class } \\
\hline Regular & 8.3 & 21.7 & 23.3 & 28.3 & 13.3 & 5.0 & 3.32 & 1.32 \\
\hline Vocational & 13.7 & 28.4 & 24.2 & 18.9 & 10.5 & 4.2 & 2.97 & 1.36 \\
\hline \multicolumn{9}{|c|}{ 18. *Feel confident when speaking English in class } \\
\hline Regular & 5.0 & 5.0 & 36.7 & 36.7 & 13.3 & 3.3 & 3.58 & 1.06 \\
\hline Vocational & 6.3 & 11.6 & 29.5 & 32.6 & 11.6 & 8.4 & 3.57 & 1.27 \\
\hline \multicolumn{9}{|c|}{ 19. Worry about English teacher correcting mistakes } \\
\hline Regular & 6.7 & 23.3 & 26.7 & 23.3 & 13.3 & 6.7 & 3.33 & 1.34 \\
\hline Vocational & 12.6 & 17.9 & 34.7 & 28.4 & 5.3 & 1.1 & 2.99 & 1.13 \\
\hline \multicolumn{9}{|c|}{ 20. Feel heart pounding when about to be called on in English class } \\
\hline Regular & 1.7 & 13.3 & 18.3 & 33.3 & 26.7 & 6.7 & 3.90 & 1.19 \\
\hline Vocational & 7.4 & 12.6 & 20.0 & 28.4 & 15.8 & 15.8 & 3.80 & 1.46 \\
\hline \multicolumn{9}{|c|}{ 21. Studying more results in more confusion about English } \\
\hline Regular & 3.3 & 13.3 & 23.3 & 36.7 & 16.7 & 6.7 & 3.70 & 1.20 \\
\hline Vocational & 9.5 & 16.8 & 27.4 & 29.5 & 12.6 & 4.2 & 3.32 & 1.28 \\
\hline \multicolumn{9}{|c|}{ 22. * Feel no pressure about being well prepared for English class } \\
\hline Regular & 6.7 & 13.3 & 31.7 & 28.3 & 13.3 & 6.7 & 3.48 & 1.27 \\
\hline Vocational & 6.3 & 12.6 & 33.7 & 26.3 & 14.7 & 6.3 & 3.49 & 1.25 \\
\hline \multicolumn{9}{|c|}{ 23. Always feel that other students speak English better } \\
\hline Regular & 0 & 8.3 & 18.3 & 31.7 & 25.0 & 16.7 & 4.23 & 1.18 \\
\hline Vocational & 6.3 & 6.3 & 18.9 & 27.4 & 20.0 & 21.1 & 4.12 & 1.44 \\
\hline \multicolumn{9}{|c|}{ 24. Feel very embarrassed when having to speak English in front of classmates } \\
\hline Regular & 0 & 10.0 & 25.0 & 40.0 & 18.3 & 6.7 & 3.87 & 1.05 \\
\hline Vocational & 15.8 & 11.6 & 29.5 & 25.3 & 8.4 & 9.5 & 3.27 & 1.46 \\
\hline \multicolumn{9}{|c|}{ 25. English class moves too quickly } \\
\hline Regular & 3.3 & 21.7 & 26.7 & 26.7 & 10.0 & 11.7 & 3.53 & 1.35 \\
\hline Vocational & 13.7 & 9.5 & 37.9 & 18.9 & 10.5 & 9.5 & 3.32 & 1.42 \\
\hline \multicolumn{9}{|c|}{ 26. Feel more tense in English class than in other classes } \\
\hline Regular & 3.3 & 20.0 & 30.0 & 28.3 & 8.3 & 10.0 & 3.48 & 1.28 \\
\hline Vocational & 15.8 & 18.9 & 41.1 & 12.6 & 6.3 & 5.3 & 2.91 & 1.30 \\
\hline \multicolumn{9}{|c|}{ 27. Feel nervous and uneasy when having to speak English in class } \\
\hline Regular & 3.3 & 11.7 & 35.0 & 35.0 & 10.0 & 5.0 & 3.52 & 1.10 \\
\hline Vocational & 12.6 & 16.8 & 27.4 & 27.4 & 10.5 & 5.3 & 3.22 & 1.35 \\
\hline \multicolumn{9}{|c|}{ 28. *Feel confident and relaxed when going to English class } \\
\hline Regular & 6.7 & 10.0 & 40.0 & 26.7 & 15.0 & 1.7 & 3.38 & 1.12 \\
\hline Vocational & 7.4 & 9.5 & 34.7 & 29.5 & 10.5 & 8.4 & 3.52 & 1.27 \\
\hline
\end{tabular}


29. Get nervous when I don't understand every word the English teacher says

$\begin{array}{lllllllll}\text { Regular } & 3.3 & 11.7 & 25.0 & 31.7 & 18.3 & 10.0 & 3.80 & 1.26 \\ \text { Vocational } & 10.5 & 10.5 & 29.5 & 35.8 & 10.5 & 3.2 & 3.35 & 1.22\end{array}$

30. Feel overwhelmed by the number of rules to learn to speak English

$\begin{array}{lllllllll}\text { Regular } & 5.0 & 13.3 & 23.3 & 31.7 & 20.0 & 6.7 & 3.68 & 1.27 \\ \text { Vocational } & 10.5 & 15.8 & 18.9 & 35.8 & 12.6 & 6.3 & 3.43 & 1.36\end{array}$

31. Worry about being laughed at by other students when speaking English

$\begin{array}{lllllllll}\text { Regular } & 5.0 & 21.7 & 40.0 & 21.7 & 6.7 & 5.0 & 3.18 & 1.16 \\ \text { Vocational } & 14.7 & 13.7 & 37.9 & 26.3 & 5.3 & 2.1 & 3.00 & 1.19\end{array}$

32. * Probably feel comfortable being around native English speakers

$\begin{array}{lllllllll}\text { Regular } & 5.0 & 6.7 & 55.0 & 21.7 & 10.0 & 1.7 & 3.30 & .98 \\ \text { Vocational } & 5.3 & 9.5 & 36.8 & 28.4 & 12.6 & 7.4 & 3.56 & 1.21\end{array}$

33. Get nervous when English teacher asks questions with no advanced preparation

$\begin{array}{lllllllll}\text { Regular } & 5.0 & 8.3 & 18.3 & 31.7 & 20.0 & 16.7 & 4.03 & 1.37\end{array}$

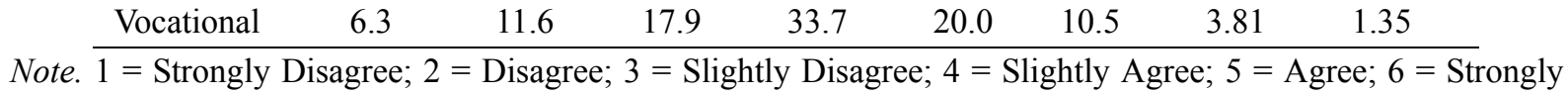
Agree.

* reverse-worded items

Among the regular high school students, the highest anxiety scores were for items 11,7 , and 23 . The scores ranged from 4.23 to 4.33 . All of the items had a high percentage of students giving responses reflective of certain degrees of anxiety. Approximately $87 \%$ of the students gave their responses to the statement in the directions showing anxiety (item 11). About $77 \%$ of the respondents showed varying degrees of agreement to the statement "I always think my classmates are better at English" (item 7). While asked whether participants feel other students speak English better (item 23), about 73\% gave responses to indicate varying degrees of anxiety.

Furthermore, for those who were in the vocational track, the top three highest anxiety scores were for Items 10, 7 and 11. The scores ranged from 4.15 to 4.42 . These participants seemed to be most worried about failing their English exam. About $76 \%$ of the respondents showed varying degrees of agreement to the statement of this item (item 10). Almost $80 \%$ of them gave responses showing agreement to the statement: "I always think my classmates are better at English" (item 7). Consistent with item 7, almost 80\% of the subjects gave responses indicating foreign language anxiety (item 11).

Both groups of students may not have had sufficient confidence so they worried that their classmates had better English abilities than they did. For example, student responses to item 10 indicated that vocational high school students were quite worried about failing their English exam. The results revealed that students feel anxious when learning a second/foreign language; this was consistent with other studies (Chang \& Wu, 2004; Jen, 2003; Kim, 2000; Liu, 2010, 2011; Saito \& Samimy, 1996; Suleimenova, 2013). Many teachers suggested that teachers try to use different approaches to help students alleviate their anxiety when learning a target language in the classroom.

\subsection{Correlation between Motivation and Anxiety}

In order to obtain a more complete picture of the relationships between variables related to language learning motivation and anxiety, Pearson product-moment correlation coefficients for all the scale and subscale scores of the full sample were calculated. The results presented in Table 4 reveal that among the MSLQ subscales, language anxiety was significantly related to both intrinsic motivation $(\mathrm{r}=-.35)$ and self-efficacy $(\mathrm{r}=-.50)$. Overall motivation of these subjects was significantly correlated with language anxiety $(r=-.33)$, which was a little lower than the correlation found in Liu's (2010) study, -.44 and -.46 at two different times in the same academic year. Still, the results reporting a significant relationship between language anxiety and motivation support the findings of previous studies (Huang, 2005; Hsu, 2004; Liu, 2012) that when students are less motivated to learn English, they are more likely to experience anxiety during the learning process.

\section{Conclusion and Implication}

The study aimed at exploring foreign language learning motivation and anxiety of two groups of students, those in the academic- and vocational-track. The findings suggested that first, academic-track students had significantly higher extrinsic motivation and overall motivation to learn English than their counterparts did. 
Second, the students participating in the current study did experience language anxiety at a moderate level. In addition, the findings revealed that learner anxiety can have some adverse impact on motivation. On the basis of the research findings, meaningful implications are suggested.

First, although academic-track high school students tend to be more extrinsically motivated than their counterparts when learning English, the differences in intrinsic motivation and other motivational subscales scores were not significant. It may be easier for students to become extrinsically motivated than intrinsically motivated. Generally, students can become extrinsically motivated when they want to achieve a goal, such as getting praise or rewards from their parents or teachers or getting admission to an ideal school. On the contrary, to become an intrinsically motivated learner, students need to feel real enjoyment and satisfaction regarding the learning task. Ryan and Deci (2000a) maintained that there is a greater chance for intrinsic motivation to be enhanced when the fundamental needs for feeling a sense of belongingness, competency, and autonomy are fulfilled. As secondary school teachers, they have to expend more efforts to cultivate and foster student learning motivation and interests in learning English. They may use more practical and authentic English materials, ask students to engage in more group activities, and have more patience when helping students. Especially for students who have lower proficiency in learning English, instructors need to spend more time helping to enlighten student extrinsic motivation and promote their intrinsic motivation because they are essential for students to learn English more effectively.

Second, EFL teachers should concur with Horwitz et al.'s (1986) viewpoint that an instructor "must acknowledge the existence of foreign language anxiety" (p. 131). Responses of two groups of students indicated that overall, they felt a moderate level of anxiety while learning English. Teachers can give students more opportunities to practice in smaller groups to help alleviate their anxiety level. Creating a more comfortable and supportive atmosphere in the English classroom can be very helpful. Moreover, as suggested by Tsiplakides and Keramida (2009), blaming and providing direct correction to students in front of other classmates should be avoided. Students need more praise and more confidence in their own competence. Further, teacher-student relationship is also an important factor. With more interaction between teachers and students, the atmosphere in the classroom can be more relaxing and lighthearted.

Several limitations of the study should be pointed out. First, due to the difficulty in recruiting two representative sample groups of subjects, academic- and vocational- track of students, the participants of the study were studying in the same high school. The result may not be generalized to all Taiwan regular and vocational high school students because these two groups of students in this study seem to be rather homogenous. Second, students in the vocational track came from Tourism and Applied Foreign Language divisions; they have more language courses or training than those in the other divisions. No students from other divisions, e.g., industrial, business, or engineering fields, were recruited to participate in the study. Finally, the instruments of the research were restricted to self-report questionnaires. To obtain a deeper understanding of the relationships among the investigated variables, interviews of students or their English teachers, open-ended questionnaires, and classroom observation could be employed in further studies.

\section{References}

Aida, Y. (1994). Examination of Horwitz, Horwitz, and Cope's construct of foreign language anxiety: The case of students of Japanese. The Modern Language Journal, 78(2), 155-168. http://dx.doi.org/10.1111/j.1540-4781.1994.tb02026.x

Au, S. Y. (1988). A critical appraisal of Gardner's social-psychological theory of second-language (L2) learning. Language Learning, 38(1), 75-100. http://dx.doi.org/10.1111/j.1467-1770.1988.tb00402.x

Awan, R. N., Azher, M., Anwar, M. N., \& Naz, A. (2010). An investigation of foreign language classroom anxiety and its relationship with students' achievement. Journal of College Teaching \& Learning, 7(11), 33-39.

Brown, J. D., Robson, G., \& Rosenkjar, P. R. (2001). Personality, motivation, anxiety, strategies, and language proficiency of Japanese students. In Z. Dörnyei, \& R. Schmidt (Eds.), Motivation and second language acquisition (Technical Report \#23, pp. 361-398). Honolulu: University of Hawaii, Second Language Teaching and Curriculum Center.

Chang, Y. C., \& Wu, G. C. (2004). A study of foreign language anxiety of EFL elementary school students in Taipei County. Journal of National Taipei Teachers College, 17(2), 287-320.

Chang. (2006). 台灣的英語教育：現況與省思。教育資料與研究雙月刊, 69, 129-144.

Chen, H. S. (2008). Motivational issues of Taiwanese vocational high school students in English as a foreign 
language classroom: An action research study (Unpublished Doctoral dissertation). Kent State University College, USA.

Chen, M. L. (2007). Vocational high school students' English learning motivation and their English learning behaviors (Unpublished Master's thesis). National Tunghai University, Taiwan.

Crookes, G., \& Schmidt, R. W. (1991). Motivation: Reopening the research agenda. Language Learning, 41(4), 469-512. http://dx.doi.org/10.1111/j.1467-1770.1991.tb00690.x

Deci, E. L., \& Ryan, R. M. (1985). Intrinsic motivation and self-determination in human behavior. New York: Plenum. http://dx.doi.org/10.1007/978-1-4899-2271-7

Dörnyei, Z. (1990). Conceptualizing motivation in foreign-language learning. Language Learning, 40(1), 45-78.

Dörnyei, Z. (1994). Motivation and motivating in the foreign language classroom. The Modern Language Journal, 78(3), 273-284.

Dörnyei, Z. (2003). Attitudes, orientations, and motivations in language learning: Advances in theory, research, and applications. Language Learning, 53, 3-32. http://dx.doi.org/10.1111/1467-9922.53222

Gardner, R. C. (1985). Social psychology and second language learning: The role of attitudes and motivation. London: Edward Arnold Publishers. http://dx.doi.org/10.1037/h0083787

Gardner, R. C., \& Lambert, W. E. (1959). Motivational variables in second-language acquisition. Canadian Journal of Psychology, 13(4), 266-272.

Gardner, R. C., \& MacIntyre, P. D. (1991). An instrumental motivation in language study- who says it isn't effective? Studies in Second Language Acquisition, 13, 57-72. http://dx.doi.org/10.1017/S0272263100009724

Gardner, R. C., Tremblay, P. F., \& Masgoret, A. M. (1997). Towards a full model of second language learning: An empirical investigation. The Modern Language Journal, 81(3), 344-362. http://dx.doi.org/10.1017/S0272263100009724

Han, W. H. (2009). A study of vocational high school students' English learning motivation, learning style, learning strategy and English learning achievement (Unpublished Master's thesis). National Chung Cheng University, Taiwan.

Ho, J. H. (1998). Sources of second language anxiety and the benefits of instructor intervention. Kwa Kang Journal of TEFL, 4, 73-104.

Horwitz, E. K. (1986). Preliminary evidence for the reliability and validity of a foreign language anxiety scale. TESOL Quarterly, 20, 559-562. http://dx.doi.org/10.2307/3586302

Horwitz, E. K., Horwitz, M. B., \& Cope, J. (1986). Foreign language classroom anxiety. The Modern Language Journal, 70, 125-132. http://dx.doi.org/10.1111/j.1540-4781.1986.tb05256.x

Hsu, S. C. (2009). Foreign language anxiety among technical college students in English class. National Formosa University Journal, 28(1), 113-126.

Hsu, Y.-T. (2004). The relationships among junior high school students' foreign language anxiety, EFL learning motivation and strategy (Unpublished Master's thesis). Cheng Kung University, Taiwan.

Huang, H.-W. (2005). The relationship between learning motivation and speaking anxiety among EFL non-English major freshmen in Taiwan (Unpublished Master's thesis). Chaoyang University of Technology, Taiwan.

Jen, C.-Y. (2003). Anxiety in English language classrooms: An investigation of Taiwanese secondary school students' foreign language anxiety in four classroom contexts (Unpublished Master's thesis). University of Bristol, United Kingdom.

Jones, B. D., Llacer-Arrastia, S., \& Newbill, P. B. (2009). Motivating foreign language students using self-determination theory. Innovation in Language Learning and Teaching, 3(2), 171-189.

Kim, J.-H. (2000). Foreign language listening anxiety: A study of Korean students learning English (Unpublished doctoral dissertation). University of Texas, Austin.

Liu, H. J. (2010). Motivation to Learn in the Ability-Grouped Foreign Language Classroom. Taipei: Crane Publishing Co.

Liu, H. J. (2011). Exploring foreign language anxiety and motivation among young adolescents in Taiwan. 
Tamsui Oxford Journal of Arts, 11, 75-92.

Liu, H. J. (2012). Understanding EFL undergraduate anxiety in relation to motivation, autonomy, and language proficiency. Electronic Journal of Foreign Language Teaching, 9(1), 123-139.

MacIntyre, P. D., \& Noels, K. A. (1996). Using social-psychological variables to predict the use of language

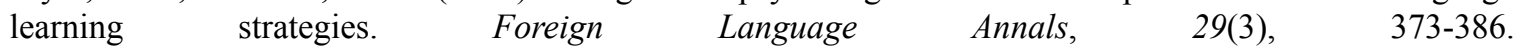
http://dx.doi.org/10.1111/j.1944-9720.1996.tb01249.x

Marcos-Llińas, M., \& Garau, M. J. (2009). Effects of language anxiety on three proficiency-level courses of Spanish as a foreign language. Foreign Language Annals, 42(1), 94-111. http://dx.doi.org/10.1111/j.1944-9720.2009.01010.x

Masgoret A. M., Bernaus, M., \& Gardner, R. C. (2001). Examining the role of attitudes and motivation outside of the formal classroom: A test of the mini-AMTB for children. In Z. Dörnyei, \& R. Schmidt (Eds.), Motivation and second language acquisition (Technical report \#23, pp. 281-295). Honolulu: University of Hawaii, Second Language Teaching and Curriculum Center.

Masgoret, A. M., \& Gardner, R. C. (2003). Attitudes, motivation, and second language learning: A meta-analysis of studies conducted by Gardner and associates. Language Learning, 53, 167-210. http://dx.doi.org/10.1111/1467-9922.00227

Noels, K. A. (2001a). Learning Spanish as a second Language: Learners' orientations and perceptions of their teachers' communication style. Language Learning, 51(1), 107-144.

Noels, K. A. (2001b). New orientations in language learning motivation: Towards a model of intrinsic, extrinsic, and integrative orientations and motivation. In Z. Dörnyei, \& R. Schmidt (Eds.), Motivation and second language acquisition (Technical report \#23, pp. 43-68). Honolulu: University of Hawaii, Second Language Teaching and Curriculum Center.

Noels, K. A., Clément, R., \& Pelletier, L.G. (1999). Perceptions of teachers' communicative style and students' intrinsic and extrinsic motivation. The Modern Language Journal, 83(1), 23-34. (ERIC DOC ED583 928). http://dx.doi.org/10.1111/0026-7902.00003

Noels, K. A., Pelletier, L. G., Clémen, R., \& Vallerand, R. J. (2000). Why are you learning a second language? Motivational orientations and self-determination theory. Language Learning, 50(1), 57-85. http://dx.doi.org/10.1111/0023-8333.00111

Okada, M., Oxford, R. L., \& Abo, S. (1996). No all alike: Motivation and learning strategies among students of Japanese and Spanish in an exploratory study. In R. Oxford (Ed.), Language learning motivation: Pathways to the new century (Technical report \#11, pp. 105-119). Honolulu: University of Hawaii, Second Language Teaching and Curriculum Center.

Onwuegbuzie, A. J., Bailey, P., \& Daley, C. E. (1997). Foreign language anxiety among college students. Paper Presented at the Annual Conference of the Mid-South Educational Research Association, Memphis, TN. (ERIC DOC ED 415 713).

Otis, N., Grouzet, F. M. E., \& Pelletier, L. G. (2005). Latent motivational change in an academic setting: A 3-year longitudinal study. Journal of Educational Psychology, 97(2), 170-183. http://dx.doi.org/10.1037/00220663.97.2.170

Oxford, R. L., \& Nyikos, M. (1989). Variables affecting choice of language learning strategies by university students. Modern Language Journal, 73(2), 291-300. http://dx.doi.org/10.1111/j.1540-4781.1989.tb06367.x

Oxford, R., \& Shearin, J. (1994). Language learning motivation: Expanding the theoretical framework. The Modern Language Journal, 78(1), 12-28. http://dx.doi.org/10.1111/j.1540-4781.1994.tb02011.x

Pintrich, P. R., \& Schunk, D. H. (1996). Motivation in education: Theory, research, and applications. Englewood Cliffs, NJ: Prentice Hall.

Pintrich, P. R., Smith, D. A. F., Garcia, T., \& McKeachie, W. J. (1991). A manual for the use of the Motivated Strategies for learning Questionnaire (MSLQ). Ann Arbor: University of Michigan, National Center for Research to Improve Postsecondary Teaching and Learning. (ERIC DOC ED 338 122).

Ryan, R. M., \& Deci, E. L. (2000a). Self-determination theory and the facilitation of intrinsic motivation, social $\begin{array}{llll}\text { development, and } \quad \text { american } & \text { Psychologist, }\end{array}$ http://dx.doi.org/10.1037/0003-066X.55.1.68 
Ryan, R. M., \& Deci, E. L. (2000b). Intrinsic and extrinsic motivations: Classic definitions and new directions. Contemporary Educational Psychology, 25, 54-67.

Saito, Y., Horwitz, E. K., \& Garza, T. J. (1999). Foreign language reading anxiety. The Modern Language Journal, 83(2), 202-218. http://dx.doi.org/10.1111/0026-7902.00016

Schmidt, R., \& Watanable, Y. (2001). Motivation, strategy use, and pedagogical preferences in foreign language learning. In Z. Dörnyei, \& R. Schmidt (Eds.), Motivation and second language acquisition (Technical Report \#23, pp. 313-359). Honolulu: University of Hawaii, Second Language Teaching and Curriculum Center.

Schmidt, R., Boraie, D., \& Kassabgy, O. (1996). Foreign language motivation: Internal structure and external connections. In R. Oxford (Ed.), Language learning motivation: Pathways to the new century (pp. 9-70). Honolulu, HI: University of Hawai i, National Foreign Language Resource Center.

Suleimenova, Z. (2013). Speaking anxiety in a foreign language classroom in Kazakhstan. Procedia - Social and Behavioral Sciences, 93, 1860-1868.

Tsao, C. T. (2012). Learners' preferred instructional activities and their English learning motivation: A study of EFL vocational high school students in Taiwan (Unpublished Master's thesis). Ming Chuan University.

Tsiplakides, I., \& Keramida, A. (2009). Helping students overcome foreign language speaking anxiety in the English classroom: Theoretical issues and practical recommendations. International Education Studies, 2(4), 39-43. http://dx.doi.org/10.5539/ies.v2n4p39

Wei, M. (2007). The interrelatedness of affective factors in EFL learning: An examination of motivational patterns in relation to anxiety in China. TESL-EJ, 11(1), 1-23.

Wen, X. (1997). Motivation and language learning with student of Chinese. Foreign Language Annals, 30(2), 235-251. http://dx.doi.org/10.1111/j.1944-9720.1997.tb02345.x

Woodrow, L. (2006). College English writing affect: Self-efficacy and anxiety. System, 39, 510-522. http://dx.doi.org/10.1016/j.system.2011.10.017

Young, D. J. (1990). An investigation of students' perspective on anxiety and speaking. Foreign Language Annals, 23(6), 539-553. http://dx.doi.org/10.1111/j.1944-9720.1990.tb00424.x

Young, D. J. (1991). Creating a low-anxiety classroom environment: What does language anxiety research $\begin{array}{lllll}\text { suggest? } & \text { The }\end{array}$ http://dx.doi.org/10.1111/j.1540-4781.1991.tb05378.x

\section{Copyrights}

Copyright for this article is retained by the author(s), with first publication rights granted to the journal.

This is an open-access article distributed under the terms and conditions of the Creative Commons Attribution license (http://creativecommons.org/licenses/by/3.0/). 